\title{
Optic disc drusen precipitating central retinal vein occlusion in young
}

\author{
Srikanta Kumar Padhy, Umesh Chandra Behera ${ }^{\odot}$
}

Retina Vitreous Service, LV Prasad Eye Institute Bhubaneswar Campus, Bhubaneswar, Odisha, India

\section{Correspondence to} umeshcbehera@gmail.com

Accepted 19 June 2019 Dr Umesh Chandra Behera,

\section{DESCRIPTION}

A 17-year-old boy presented with sudden painless diminution of vision in right eye for 3 days. The best corrected visual acuity was 20/400 and $20 / 20$ in right and left eye, respectively. The intraocular pressures were $12 \mathrm{~mm} \mathrm{Hg}$ in both eyes. There was associated relative afferent pupillary defect in right eye (OD). Anterior

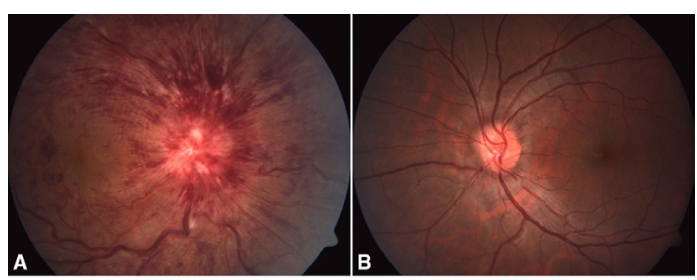

Figure 1 Colour fundus photograph of right eye (A) shows hyperemic and swollen disc with extensive intraretinal and disc haemorrhages suggestive of CRVO. Similar optic disc features sans the retinal haemorrhages in left eye (B) is suggestive of pseudopapilloedema. CRVO, central retinal vein occlusion.
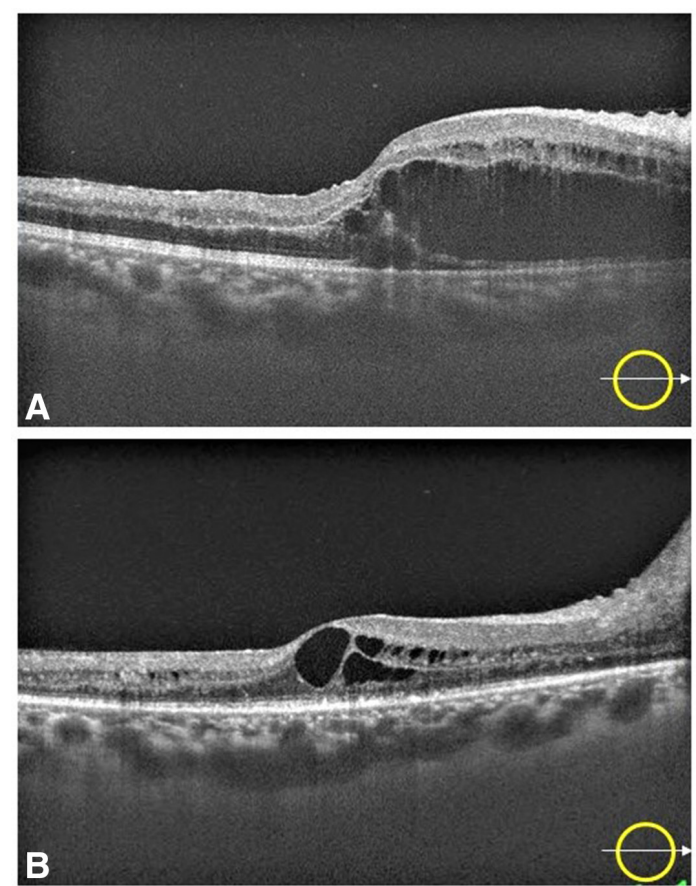

Limited 2019. No commercia re-use. See rights and permissions. Published by BMJ.

\begin{tabular}{|l|}
\hline To cite: Padhy SK, \\
Behera UC. BMJ Case \\
Rep 2019;12:e230677. \\
doi:10.1136/bcr-2019- \\
230677 \\
\hline
\end{tabular}
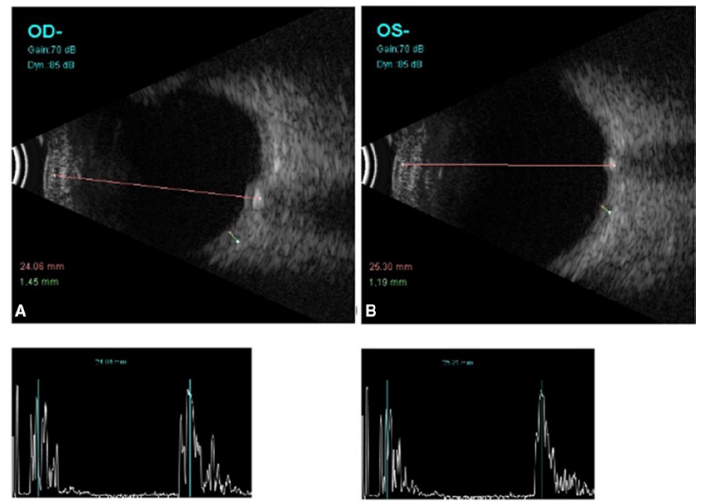

Figure 3 Ultrasound B-scan image shows high reflective ovoid lesion at the optic disc representative of optic disc drusen in both eyes. OD, right eye; OU, both eyes.

segment examination was otherwise normal in both eyes (OU). Dilated fundus examination OD revealed optic disc oedema with hyperaemia, extensive intraretinal haemorrhages, engorged tortuous veins, macular oedema and cotton wool spots (figure 1A). Left eye had a swollen disc with blurred margins and the physiological cup was obscured(figure 1B). Optical coherence tomography (OCT) through macula in right eye showed thickened retinal nerve fibre layer, intra-retinal cystoid spaces and neurosensory detachment (figure 2A). B-scan ultrasound revealed pronounced disc oedema OD and an ovoid echogenic lesion deep within the optic disc with corresponding high amplitude spike on A-scan OU (figure $3 \mathrm{~A}, \mathrm{~B}$ ). He did not report any medical history and was not on any systemic medications. Based on above clinical and imaging findings, a diagnosis of optic disc drusen OU and central retinal vein occlusion (CRVO) with macular oedema OD was made. Investigations for thromboembolic risk factors were unremarkable. His blood pressure (120/80 mm Hg), fasting blood glucose (86 mg/ $\mathrm{dL})$ and serum lipid profile were normal. The macular oedema ebbed with two intravitreal bevacizumab $(1.25 \mathrm{mg})$ injections at 1 month intervals and the corrected vision improved to $20 / 80$ at 3 months before he was lost to follow-up (figure 2B).

Optic disc drusen are calcified hyaline-like deposits in the optic nerve head concentrated anterior to the lamina cribrosa. ${ }^{1}$ It's incidence is $0.4 \%-20.4 \%$ in general population with female preponderance. ${ }^{2}$ They are often bilateral 
Table 1 Patient demographics of the reported cases of CRVO association in eyes with optic disc drusen

\begin{tabular}{|c|c|c|c|c|c|}
\hline Author & Year & Age/sex & CRVO severity & Systemic association & Treatment \\
\hline Brodrick $^{12}$ & 1973 & 48 years/ female & $\begin{array}{l}\text { Optic nerve head drusen associated with extensive } \\
\text { retinal haemorrhages }\end{array}$ & Hypertension & None \\
\hline Chern et a $\left.\right|^{13}$ & 1991 & 43 years/ male & Non-ischaemic CRVO & No systemic associations & None \\
\hline Gallagher and Clearkin ${ }^{14}$ & 2000 & 33 years/ female & Non-ischaemic CRVO & On oral contraceptives & None \\
\hline Honkanen et al ${ }^{9}$ & 2011 & 13 years/male & Ischaemic CRVO & No systemic associations & Pan-retinal photocoagulation \\
\hline Law et $a l^{2}$ & 2014 & 52 years/ male & Non-ischaemic CRVO No macular involvement & No systemic associations & None \\
\hline
\end{tabular}

CRVO, central retinal vein occlusion.

$(67 \%-91 \%)$ and are commonly found at the nasal aspect of the optic disc. ${ }^{2}$ Largely they are benign and vision sparing but rarely may complicate with visual field defects, haemorrhages, choroidal neovascularisation, serous maculopathy and non-arteritic ischaemic optic neuropathy. ${ }^{3-5}$ Enlargement of drusen with advancing age is believed to cause mechanical compression at the lamina cribrosa leading to the complications. ${ }^{1}$ Elevation of central retinal venous pressure may result in CRVO. ${ }^{126}$ The enlargement is observed mostly in teenage ${ }^{78}$ but to the best of our knowledge only a single case has been reported with concomitant CRVO in teenage. ${ }^{9}$ Unlike the hitherto reported case which resulted in neovascular glaucoma and retinal detachment, we achieved favourable outcome with intravitreal bevacizumab injection in the early treatment period. Follow-up at a later date could throw light on the long-term course of this vascular occlusion. This underscores active and early treatment of symptomatic CRVO in young when associated with optic disc drusen. Universal eye screening in children could go a long way detecting optic disc drusen early and imaging modalities such as ultrasound B scan and enhanced

\section{Patient's perspective}

I am happy that my disease could be diagnosed accurately at an early stage and the treatment in the form of eye injection restored my vision. I was informed about the rarity of the haemorrhagic complication and the risk of the other eye being involved.

\section{Learning points}

- Subjects with optic disc drusen should be made aware of the ominous prospects of a venous occlusion and followed closely.

- Ultrasound B scan of optic nerve head is a simple imaging tool to reveal embedded drusen.

- Optic disc drusen should be one of the differentials in young onset central retinal vein occlusions. depth optical coherence tomography can increase the sensitivity of the detection in buried drusen. ${ }^{10} 11$ Table 1 lists the reported association of optic disc drusen with CRVO in literature.

Acknowledgements Hyderabad Eye Research Foundation.

Contributors SKP was involved in conceptualisation, data collection, manuscript writing and critically reviewing the manuscript. UCB was involved in planning, conceiving and conducting the study. He also wrote and critically reviewed the manuscript.

Funding The authors have not declared a specific grant for this research from any funding agency in the public, commercial or not-for-profit sectors.

Competing interests None declared.

Patient consent for publication Obtained.

Provenance and peer review Not commissioned; externally peer reviewed.

\section{REFERENCES}

1 Auw-Haedrich C, Staubach F, Witschel H. Optic disk drusen. Surv Ophthalmol 2002:47:515-32.

2 Law DZ, Yang FP, Teoh SC. Case report of optic disc drusen with simultaneous peripapillary subretinal hemorrhage and central retinal vein occlusion. Case Rep Ophthalmol Med 2014;2014:1-4.

3 Sarkies NJ, Sanders MD. Optic disc drusen and episodic visual loss. Br J Ophthalmol 1987;71:537-9.

4 Katz BJ, Pomeranz HD. Visual field defects and retinal nerve fiber layer defects in eyes with buried optic nerve drusen. Am J Ophthalmol 2006;141:248-53.

5 Romero J, Sowka J, Shechtman D. Hemorrhagic complications of optic disc drusen and available treatment options. Optometry 2008;79:496-500.

6 Rubinstein K, Ali M. Retinal complications of optic disc drusen. Br J Ophthalmol 1982;66:83-95.

7 Malmqvist L, Lund-Andersen H, Hamann S. Long-term evolution of superficial optic disc drusen. Acta Ophthalmol 2017;95:352-6.

8 Frisén L. Evolution of drusen of the optic nerve head over 23 years. Acta Ophthalmol 2008:86:111-2.

9 Honkanen RA, Baba FE, Sibony P, et al. Ischemic central retinal vein occlusion and neovascular glaucoma as a result of optic nerve head drusen. Retin Cases Brief Rep 2011;5:73-5.

10 Goyal P, Padhi TR, Das T, et al. Outcome of universal newborn eye screening with wide-field digital retinal image acquisition system: a pilot study. Eye 2018;32:67-73.

11 Merchant KY, Su D, Park SC, et al. Enhanced depth imaging optical coherence tomography of optic nerve head drusen. Ophthalmology 2013;120:1409-14.

12 Brodrick JD. Drusen of the disc and retinal haemorrhages. Br J Ophthalmol 1973;57:299-306.

13 Chern S, Magargal LE, Annesley WH. Central retinal vein occlusion associated with drusen of the optic disc. Ann Ophthalmol 1991;23:66-9.

14 Gallagher MJ, Clearkin LG. Drug or drusen? Central retinal vein occlusion in a young healthy woman with disc drusen. Eye 2000;14:401-2. 
Copyright 2019 BMJ Publishing Group. All rights reserved. For permission to reuse any of this content visit https://www.bmj.com/company/products-services/rights-and-licensing/permissions/

BMJ Case Report Fellows may re-use this article for personal use and teaching without any further permission.

Become a Fellow of BMJ Case Reports today and you can:

- Submit as many cases as you like

- Enjoy fast sympathetic peer review and rapid publication of accepted articles

Access all the published articles

Re-use any of the published material for personal use and teaching without further permission

Customer Service

If you have any further queries about your subscription, please contact our customer services team on +44 (0) 2071111105 or via email at support@bmj.com.

Visit casereports.bmj.com for more articles like this and to become a Fellow 